AGRICULTURE AND BIOLOGY JOURNAL OF NORTH AMERICA

ISSN Print: 2151-7517, ISSN Online: 2151-7525, doi:10.5251/abjna.2012.3.10.391.399

(C) 2012, ScienceHuß, http://www.scihub.org/ABJNA

\title{
The effects of four strains of mycorrhizal fungi and goat manure on fodder production by Moringa oleifera under rain-fed conditions in the Gambia
}

\author{
Asaolu$^{1}$, V. O., Odeyinka ${ }^{2}$, S. M. and Akinbamijo ${ }^{3}$, 0. O. \\ ${ }^{1}$ International Trypanotolerance Centre, Banjul, The Gambia \\ ${ }^{1}$ Department of Animal Nutrition and Biotechnology, Ladoke Akintola University of \\ Technology, Ogbomoso, Nigeria (Current affliation) \\ ${ }^{2}$ Department of Animal Sciences, Obafemi Awolowo University, lle-lfe, Nigeria \\ ${ }^{3}$ Agriculture and Food Security Division, African Union Commission, Addis Ababa, Ethiopia.
}

\begin{abstract}
Four myccorhizal fungi strains \{Glomus facultative, Glomus mossae, Glomus agregatum and Glomus intraradices \} and goat manure were assessed as options to NPK fertilization on fodder production by Moringa oleifera over a 60-day growing period in a randomized complete design. Germination percentages, average plant heights, canopy formation, biomass yields and fodder:stem ratios were monitored. Experimental soil samples' and resulting moringa fodders' contents of $\mathrm{N}, \mathrm{P}$ and $\mathrm{Ca}$ were assessed. No fertilization $(\mathrm{P}>0.05)$ effects were observed on germination percentage and plant height at germination. The myccorhizal fungi (except Glomus facultative), NPK and goat manure produced comparable moringa biomass yields, with each treatment producing above 4 tons $\mathrm{DM} /$ ha. Fertilization effects $(\mathrm{P}<0.05)$ were however observed on plant height at harvest, final canopy formation and the resulting fodder:stem ratios. No significant $(P>0.05)$ effects were observed on the mineral contents of the moringa fodders, while a significant $(\mathrm{P}<0.05)$ depletion in available soil $\mathrm{P}$ was observed. Two of the investigated mycorrhizal fungi; Glomus agregatum and Glomus mossae, and goat manure applications could be practical alternatives to chemical fertilization in the cultivation of Moringa oleifera for fodder production, with goat manure having the edge in terms of relative availability, cost and nutrient recycling.
\end{abstract}

Keywords: Moringa oleifera, arbuscular mycorrhizal fungi, goat manure, The Gambia

\section{INTRODUCTION}

Agriculture is the main source of income for many Gambians, with most of the population depending on subsistence agriculture (NAPA, 2007). Mixed croplivestock farming is practiced throughout the country, although there are local variations related to ethnic traditions and preferences (PSIP, 2007). Groundnut (Arachis hypogea) is the dominant crop, with significant hectarage of grain crops, such as millet (Pennisetum glaucum) and maize (Zea mays), also present (Peter and Schulte, 1996). In The Gambia, livestock contributes approximately $24 \%$ of the agricultural gross domestic product, with an estimated growth rate of $3.3 \%$ (FAO, 1997). Beef and dairy cattle as well as small ruminant production in the country are predominantly based on the free range pastoral system (NAPA, 2007). Rangelands cover an area of about 500,000 ha across the country (NEA, 1997; Bobb et al., 2005). Rangeland vegetation is dominated by Andropogon spp. Fodder trees, which thinly populate the rangelands, include Acacia seyal, Daniella oliveri, Ceiba pentranda, Moringa oleifera and Pterocarpus erinaceus. Natural pressure on rangeland comes from rainfall variability and sustained periods of hot weather (NAPA, 2007). The acknowledged negative climatic changes (Nkomo and Gomez, 2005) have resulted in a continuous shrinkage of rangelands (NAPA, 2007) and also negatively impacted on groundnut hay availability, the traditional feed resource of choice for ruminants in urban and peri-urban areas (Akinbamijo et al., 2004). According to Bobb et al. (2005), a 29 $40 \%$ drop in biomass, depending on species considered, is expected to accompany projected climate changes. Cole et al. (2005) estimated that there will be a $40 \%$ drop in groundnut yields due to rising temperatures, with a resultant drop in groundnut hay availability. It therefore became necessary to investigate the potentials of alternative feed resources. The International Trypanotolerance 
Centre (ITC), Banjul, The Gambia, therefore, screened more than thirty five feed resources that can be used by urban ruminants as basal and/or supplement diets (Akinbamijo et al., 2004), and also with a focus on the need to strengthen the biocapacity of rangelands at the national level. Moringa oleifera was identified as a promising candidate for this twin-objective as it can be established on large scales using the intensive feed garden approach.

Although the productivity of moringa in industrial plantations can be very high, there is need for continued research to find out whether, in the long run, this kind of productivity is truly sustainable, and at what costs (Foidl et al., 2001). The approach has been reported (Akinbamijo et al., 2004; Radovich, 2009) to make high demands on water and fertilizer requirements for optimum production. A fertilization regime of $50 \mathrm{~kg} / \mathrm{ha} /$ month with NPK compound fertilizer was observed as imperative for high biomass yields in some preliminary studies at the ITC (Akinbamijo et al., 2004). Olivier (No date) reported that after several trials by the Church World Service (CWS) at a location north of Dakar, Senegal, the best performing results were observed with between 32 and $48 \mathrm{~kg}$ NPK per week, depending on the visible condition of the plants. Access to fertilizer is however limiting and usage very low, especially among subsistence farmers in The Gambia and those in other sub-Saharan nations (Ceesay, 2004). This situation has been associated with the high cost of fertilizer importation and transportation to the rural areas. In The Gambia, in absolute values, nitrogen costs between $\$ 2$ and $\$ 3$ per kg when applied as 1515-15 or 8-24-24 NPK fertilizer, while phosphorus and potassium cost between $\$ 1$ and $\$ 2$ when applied as one of the two combinations (FAO, 2002).

Reports are found in the literature on the use of natural approaches to mitigate the effects of chemical fertilization as well as cut down on production costs for some crops. Inoculation with arbuscularmycorhizal fungi (AMF) is a promising strategy to enhance plant growth and $P$ nutrition while reducing inputs in the tropics (Radovich, 2009). AMF are obligate symbionts that colonize the roots of most terrestrial plants, which generally benefit from this AMF association through increased plant nutrient uptake, plant growth and survival rates (Akhtar and Siddiqui, 2007; Smith and Read, 2008). The AMF association may also increase the host plant resistance/tolerance against biotic ( $\mathrm{Hol}$ and Cook, 2005; Akhtar and Siddiqui, 2007), and abiotic stresses including salinity and drought (Smith, 1987;
Sudova et al., 2007). Many species of AMF are known to exist, and plant host response differs with the different fungal species (Carling and Brown, 1980; Wilson, 1988). However, there is a dearth of information on the mycorrhizal status and inoculation of Moringa oleifera, with only a few reports (Farias et al., 2008; Radovich, 2009; Yamato et al., 2009) being available. Farias et al. (2008) assessed the responses of Moringa oleifera plants inoculated with mycorrhizal fungi and submitted to water stress while Radovich (2009) evaluated two genotypes of Moringa oleifera ('PKM-2' and 'Hawaii') and one accession of Moringa stenopetala (Steno) for their response to inoculation with Glomus aggregatum. Yamato et al. (2009) reported on the community structure of AMF in the roots of Moringa spp. in semiarid regions in Madagascar and Uganda. In spite of the limited available data, it has been established that generally, the majority of vegetable crops and fruit trees that are important in human and animal nutrition form symbiotic associations with AMF (Nair, 1998; Ambe, 2001). Hence, it is important to explore the possibility of utilizing these micro-symbionts in agriculture, and thus make it possible to encourage healthy cultural systems by reducing the use of chemical inputs, and sustain a better productivity and ecosystem preservation (Guissou, 2009). Some reports (Mahn et al., 2005; Oliveira Jr. et al., 2009) are available on the application of different animal manures in moringa cultivation, with Oliveira Jr. et al. (2009) reporting that chicken manure applied at 10 tons/ha had an edge over cattle and goat manures applied at 20 tons/ha each, in terms of plant height and diameter up to 90 days after sowing.

With the above in mind and within the West African farming context, the present study assessed four strains of myccorhizal fungi (Glomus facultative (Gf), Glomus mossae (Gm), Glomus agregatum (Ga) and Glomus intraradices (Gi) and goat manure as organic fertilization options to NPK (15-15-15) application on the agronomic performance of Moringa oleifera for biomass production using the intensive cultivation approach.

\section{MATERIAL AND METHODS}

Experimental site: The study was conducted between July and September, 2007 at the ITC, Banjul, The Gambia. ITC is located in Kerr Serrigne, which lies between the latitude $14^{\circ} 45^{\prime}$ and $16^{\circ} 45^{\prime}$ (Diack et al., 2005). The country is classified as a semi-arid zone in agro-climatic terms (Bourn et al., 2001), with one wet season (June - October) followed by a seven month dry season; November till May 
(Agriculture and Farming in The Gambia, 2012). Production on $98 \%$ of cropland in The Gambia relies on rainfall (Nkomo and Gomez, 2005).

Acquisition of moringa seeds, AM fungi, NPK fertilizer and goat manure: The seeds used in this study were sourced from Radville farms, Nemakunku. The farm is at the forefront of vegetable production for the export market in The Gambia. They were thoroughly cleaned of all impurities before being planted. Spores of the four strains of AM fungi that were used in this study were obtained from MIRCEN/Laboratoire Commun de Mocrobiogie IRDISRA-UCAD, Dakar, Senegal, while the compound NPK (15-15-15) fertilizer was purchased from a reputable agro-chemical store at Brikama, located in the Western region of The Gambia. Goat faecal droppings were collected from the Small Ruminant Unit of ITC, sun-dried, partially pulverized and bagged during the dry season preceding the study.

Soil analysis, land preparation and plot establishment: Prior to land preparation, soil samples were taken with an auger randomly to a depth of about $15 \mathrm{~cm}$ from 200 spots from the experimental site. The samples were bulked, air-dried and ground to pass through a $2 \mathrm{~mm}$ mesh. Samples of the soil were leached by Ammonium acetate (NH4Ac). Total nitrogen $(\mathrm{N})$ was determined by micro-kjeldahl method and available phosphorus $(\mathrm{P})$ by molybdenum blue colorimetry after Bravay- 1 extraction. The calcium $(\mathrm{Ca})$ content was obtained by titration while magnesium $(\mathrm{Mg})$ was determined by the use of atomic absorption spectrophotometer. The $\mathrm{pH}$ was determined by using a digital electronic $\mathrm{pH}$ meter at soil : water (2:1) suspension. The hydrometer method was used for particle size analysis. The experimental site, measuring about 0.012 ha, was prepared by conventional tillage; clearing the land of weeds followed by ploughing and mapping out into seven (7) plots of an equal number of sub-plots each with each sub-plot for an experimental treatment, giving a total of 49 experimental units. Each of the 7 fertilization treatments was allocated to every plot using a complete randomized design (CRD). Each sub-plot measured $1.5^{\star} 1.5 \mathrm{~m}$ with a spacing of $1 \mathrm{~m}$ between sub-plots for ease of movement during cultural operations. Establishment was by direct seeding in the field at a depth of about $2 \mathrm{~cm}$ as recommended by Sharma and Raina (1982), with 2 seeds/hole and at a spacing of $20^{\star} 20 \mathrm{~cm}$ to give 250,000 plants/ha. There were six fertilizer application treatments, which comprised of inoculation with four strains of AM fungi
(Glomus facultative (Gf), Glomus mossae (Gm), Glomus agregatum (Ga) and Glomus intraradices (Gi), mineral fertilization with NPK, and goat manure application (GM) with zero fertilization (ZF) as a control. Control of weeds was done manually twice $\left(3^{\text {rd }}\right.$ and $6^{\text {th }}$ weeks) before harvesting for biomass evaluation. Soil sampling and analysis were repeated on completion of the study.

Fertilizer application and myccorhizal inoculation techniques: With about four weeks to the commencement of the study, the stored dry and partially pulverized goat manure was manually incorporated into the sub-plots designated for this treatment at about 2.5 tons DM/ha. AM fungi inoculations were done at $10 \mathrm{~g} / \mathrm{hole}$ simultaneously with seed sowing. NPK was broadcasted at the rate of $50 \mathrm{~kg} / \mathrm{ha}$ immediately after planting, and this was repeated four weeks after germination.

Assessment of performance indices: Data were collected on germination percentage, canopy formation and plant height at two (2) weeks and subsequently weekly until harvesting. Plants were harvested from within a randomly-placed 1 -m quadrat within each sub-plot 60 days after planting at $20 \mathrm{~cm}$ above ground level for biomass yield evaluation, which was done with a weighing scale on the field. Five (5) plants were randomly selected from each quadrat and pooled together for each treatment, and thereafter taken to the farm house equipped with electronic balances for fodder:stem ratio determination of the resulting biomasses. Leaves, soft stems and twigs that could be used as animal fodder were considered as the "fodder" fraction, while the hard and woody part that could not be used as livestock fodder was regarded as the "stem" fraction. The "fodder" fractions were sampled, and the samples were pooled together for each treatment and oven-dried at $70^{\circ} \mathrm{C}$ for 48 hours for dry matter (DM) determination. The samples were milled to pass through a $1 \mathrm{~mm}$ sieve. Total nitrogen $(\mathrm{N})$ was determined by Kjeldahl procedure (AOAC, 2000). Acid detergent fibre (ADF) and neutral detergent fibre (NDF) contents were analyzed with ANKOM Technology Methods (2001a and b). P and $\mathrm{Ca}$ contents were measured with the aid of an atomic absorption spectrophotometer.

Statistical analyses: Soil property differences between pre-planting and post-harvest periods were analyzed using the student' t-test, while the other performance indices were subjected to ANOVA using the GLM of SAS (1998). Significant differences were separated by DNMRT of the same package. 


\section{RESULTS AND DISCUSSION}

Pre-planting and post-harvest soil characteristics: Results of soil analyses at the experimental site, pre-planting and post-harvest, were as shown on Table 1. The experimental site was slightly acidic going by the observed $\mathrm{pH}$ values (6.40 and 6.45), with a low content of organic matter (1.40 - $1.45 \%$ organic C). The results of the particle size analyses (Sand : Silt : Clay; 70 : 19.5 : 10.5) showed the presence of sandy loam soil. Comparable amounts of nutrients, except for available $\mathrm{P}$, were available in the soil, pre-planting and post-harvest. Although the experimental site was grossly sampled for soil analysis, some earlier reports (Olayinka, 1990; Smith and Ayenigbara, 2001; Awodun et al., 2007) indicate increased availability of cations with goat manure and NPK fertilizer applications. Olayinka (1990) attributed the effect of NPK to increased organic matter contents while Awodun et al. (2007) related the effects of goat manure to increase in soil $\mathrm{pH}$. Nonetheless, the obtained values were within the ranges reported by Ceesay (2004) in Western Region of The Gambia. According to Price (2005), moringa does well in welldrained sandy or loamy soil, but the soil should not be water-logged. It will tolerate a wide $\mathrm{pH}$ range (5.0 9.0), and grows well in alkaline conditions of up to a $\mathrm{pH}$ of 9.0. In general, soil organic matter is low in Gambian soils (Ceesay, 2004). This has been attributed to the long dry season and the consumption of crop residues off the field by livestock, resulting in very little above-ground residue being returned to the soil. Although the experimental site had been left to fallow for about three years before the study, the Centre's (ITC) milking herd, comprised mainly of $\mathrm{F} 1$ crosses from N'Dama $\times$ Holstein Friesian cattle breeds, repeatedly grazed the area as part of their feeding plan for the period. Soil organic matter makes a critical contribution to soil fertility. It contains $95 \%$ or more of the total $\mathrm{N}$ present in most soils, and in some, it may contain as much as $60 \%$ of the total phosphorus and $80 \%$ of total sulphur (Ceesay, 2004). In a study of soil nutrients in The Gambia, Peters and Schulte (1996) reported the following widespread deficiencies $\mathrm{Z}>\mathrm{S}>\mathrm{N}>\mathrm{P}>\mathrm{K}$. Under drought conditions, phosphorus could be more deficient (Ceesay, 2004). However, the arbuscular mycorrhizal fungi are well known to facilitate plant mineral nutrient uptake, particularly under conditions of P-limitation, as it is common in tropical soils due to leaching and/or severe immobilization. The depleted status of available $P$ post-harvest could probably be attributed to this phenomenon. There are limited reports in this area with moringa. The only available one evaluated two genotypes of Moringa oleifera ('PKM-2' and 'Hawaii') and one accession of Moringa stenopetala (Steno) for their response to inoculation with Glomus aggregatum under varied soil solution $P$ concentrations in two greenhouse experiments. The response of the three genotypes varied significantly and was dependent on soil solution $P$ concentration. Dry matter accumulation and tissue $P$ levels of all genotypes were generally enhanced by inoculation at relatively low soil-solution $P$ concentrations $(0.009$ $0.02 \mathrm{mg} \mathrm{L}^{-1}$ ).

Table 1:Pre-planting and post-harvest physicochemical properties of the experimental site' soil.

\begin{tabular}{|c|c|c|}
\hline Properties & $\begin{array}{c}\text { Pre-planting } \\
\text { values }(0-15 \\
\mathrm{cm})\end{array}$ & $\begin{array}{c}\text { Post-harvest } \\
\text { values }(0-15 \\
\mathrm{cm})\end{array}$ \\
\hline \multicolumn{3}{|l|}{ Chemical } \\
\hline $\mathrm{pH}\left(2: 1 \mathrm{H}_{2} \mathrm{O}\right)$ & 6.40 & 6.45 \\
\hline Organic C (\%) & 1.40 & 1.45 \\
\hline Total N (\%) & 0.34 & 0.35 \\
\hline $\begin{array}{c}\text { Available P }(p p m) \\
\text { Bray } 1\end{array}$ & $0.32^{\mathrm{a}}$ & $0.25^{b}$ \\
\hline $\begin{array}{c}\mathrm{Ca}^{2+} \text { meq/100g } \\
\mathrm{NH}_{4} \mathrm{OAc}\end{array}$ & 0.24 & 0.25 \\
\hline \multicolumn{3}{|l|}{ Physical } \\
\hline Sand (\%) & 70.0 & 70.0 \\
\hline Silt (\%) & 19.50 & 19.50 \\
\hline Clay (\%) & 10.50 & 10.50 \\
\hline Textural class & Sandy loam & Sandy loam \\
\hline
\end{tabular}

${ }^{\mathrm{abc}}$ Means in the same row with different superscripts are statistically different at $5 \%$ level of significance.

Fertilization effects on growth parameters and above-ground biomass production: Table 2 shows the germination, growth and above-ground biomass yield responses of Moringa oleifera to different fertilization regimes. Irrespective of the fertilization regime, germination was observed to have been completed by the $14^{\text {th }}$ day after sowing, and the germination percentage ranged between 80 and 84 $\%$ with no significant $(P>0.05)$ treatment effects. Plant height at germination was also not significantly $(P>0.05)$ affected by the fertilization regimes; with values ranging from 14.75 to $16.38 \mathrm{~cm}$. Germination percentage, defined as the percentage of seeds from a seed population that produce a seedling (Hartmann et al., 2002), is principally affected by temperature, oxygen, water and light, of which temperature is the most significant (Hartmann et al., 2002). The germination of Moringa oleifera seed is hypogeal, that is, the cotyledons remain beneath the soil 
surface where they have been deposited (De Vogel, 1980). The germination percentage ranges between 60 and $90 \%$ for fresh seeds (Jahn et al., 1986) and the seed germinates at between 7 and 30 days after sowing (Sharma and Raina, 1982). Hydropriming for 12 hours before sowing could have influenced the germination percentages to have risen close to the upper limit of $90 \%$. Available reports (Tedonkeng et al., 2004; Nouman et al., 2012) indicate that hydropriming increases the germination of moringa seeds. It is further reported to increase shoot length, and fresh and dry weights of moringa seedlings as well as increase the multiplication of shoot tip cells (Bose and Mishra, 1992; Nouman et al., 2012). Hydropriming has also been reported (Santos et al., 2011) to an effective tool to induce tolerance in moringa seeds to salt stress, and has been described by Nouman et al. (2012) as organic, inexpensive and environmentally-friendly.

Fertilization effects $(P<0.05)$ were observed on plant height at harvest, which was done 60 days after planting. Plant heights ranged between from slightly over $40 \mathrm{~cm}$ to about $65 \mathrm{~cm}$. Ga, Gm fertilization regimes produced the highest plants while the shortest plants were observed with Gi fertilization. These values appeared moderate to fairly high when compared to reported values (Morton, 1991; Nouman et al., 2012). Morton (1991) reported that moringa seedlings gained a height of 20 to $30 \mathrm{~cm}$ after 6 weeks of sowing, while Nouman et al. (2012) reported a height of $30 \mathrm{~cm}$ after 20 days of sowing. Fertilization effects $(P<0.05)$ were also observed with canopy formation, biomass yield and fodder:stem ratio. NPK fertilization produced the largest canopy $(82.50 \%)$, and correspondingly highest biomass yield (4.53 tons/ha) and fodder:stem ratio (80:20). Moringa plants with goat manure application followed in terms of the three performance indices. Canopy formation for plants with $\mathrm{Ga}(52.50 \%)$ and $\mathrm{Gm}(54.38 \%)$ were comparable to what was observed for the control plants $(55.63 \%)$ while Gf and Gi produced smaller canopies; 34.38 and $36.25 \%$ respectively. In The Gambia, drought at the time of crop germination (immediately after planting) and late season drought (terminal drought) are often the most critical (Ceesay, 2004). Hence, the possible beneficial effects of a large canopy size on plant recovery following possible drought cannot be down-played. Rice genotypes in The Gambia with bigger canopy size are reportedly (Fukai, 1999) more severely affected by early-season drought, as leaf water potential decreases rapidly and a large number of green leaves are lost. However, there may still be a higher leaf area index at the end of the drought period because of their large canopy size at the beginning, and they could then recover more quickly and produce more biomass (Fukai, 1999). Although NPK fertilization produced the largest $(P<0.05)$ biomass, all the other fertilization options, except Gf and the control (ZR), produced more than 4.0 tons/ha each. However, GM fertilization produced a significantly $(P<0.05)$ higher biomass relative to all the four mycorrhizal fungi that were investigated. A similar trend was observed for the fodder portions of the respective biomasses when they were partitioned into fodders and coarse stems. The biomass yields obtained in this study (3.83 - 4.53 tons DM/ha at 250,000 plants/ha) seemed in tandem with the report of Foidl et al. (2001). The researcher reported 3.33 and 5.05 metric tons of moringa DM at first cutting at for 95,000 and 350,000 planting densities respectively. In this study, NPK fertilizer produced the highest $(P<0.05)$ yield of 4.53 tons/ha followed by goat manure (4.36 tons/ha). Similar observations with Indian spinach were attributed by Smith and Ayenigbara (2001) to a quicker release of N, P and K from the fertilizer. The relative importance of the different fertilization options to produce useful fodder, that is, leaves and soft stems and twigs, is shown by the fodder:stem ratios (NPK $>\mathrm{GM}>\mathrm{Gm}=\mathrm{Ga}=\mathrm{Gf}=\mathrm{Gi}$; Table 2). Awodun et al. (2007) reported increased number of tomato leaves with NPK and goat manure applications.

Effects of fertilization regimes on nutrient concentrations of Moringa oleifera fodder: No significant $(P>0.05)$ effects of the experimental fertilization regimes were observed on the nutrient concentrations of moringa fodder (Table 3). The resulting fodders were succulent with dry matter contents within the range of 27 and $28 \%$; comparable to what was obtained for other commonly utilized browses (Aregheore, 2004). Nitrogen (N) contents, widely acknowledged as indicators of crude protein value, were comparable (3.05 - 3.20) for all the fertilization regimes. These values could be regarded as relatively high when compared with those of tropical grasses on which most ruminants depend, which seldom exceed 2.4 (Reynolds et al., 1992). The crude protein of moringa has also been reported (Becker, 1995) to be of better quality for ruminants because of its high content of by-pass protein $(47 \%$ versus $30 \%$ and $41 \%$ for gliricidia and leucaena, respectively). Gliricidia and leucaena are two of the most commonly-utilized browses in ruminant nutrition (Odeyinka et al., 2003). The contents of fibre fractions, as represented by acid 
detergent fibre $(25.80-28.50 \%)$ and neutral detergent fibre $(35.50-36.50 \%)$, all fell within the ranges that were described by Okoli et al. (2003) as low to moderate when compared with low quality roughages which ruminants can effectively degrade. Apart from N, two other elements which are considered essential in ruminant nutrition and whose levels of presence in forages determine pasture quality are phosphorus $(\mathrm{P})$ and calcium $(\mathrm{Ca})$. Forages are generally good sources of $\mathrm{Ca}$ while $\mathrm{P}$ availability varies with plant maturity and drought conditions among other factors (Norton, 1998). The most devastating economic effect of phosphorus deficiency is documented to be reproductive failure, with phosphorus supplementation drastically increasing fertility levels in grazing cattle in many parts of the world (McDowell, 1985). In this study, all the fodders resulting from the various fertilization regimes contained $\mathrm{Ca}$ and $\mathrm{P}$ levels higher than critical levels (McDowell, 1985) for small ruminants and cattle.

Table 2: Effects of different fertilization regimes on growth parameters and above-ground biomass production of Moringa oleifera

\begin{tabular}{|c|c|c|c|c|c|c|}
\hline $\begin{array}{c}\text { Fertilization } \\
\text { regime }\end{array}$ & $\begin{array}{c}\text { Germination } \\
(\%)\end{array}$ & \multicolumn{2}{|c|}{ Plant height (cm) } & $\begin{array}{c}\text { Canopy } \\
\text { formation (\%) }\end{array}$ & $\begin{array}{c}\text { Biomass yield } \\
\text { (DM tons/ha) }\end{array}$ & $\begin{array}{c}\text { Fodder:Stem } \\
\text { ratio }\end{array}$ \\
\hline ZR & 80.63 & 16.38 & $59.88^{\mathrm{b}}$ & $55.63^{\mathrm{C}}$ & $3.83^{\mathrm{d}}$ & $75: 25^{\mathrm{C}}$ \\
\hline NPK & 82.50 & 16.00 & $65.75^{\mathrm{a}}$ & $82.50^{\mathrm{a}}$ & $4.53^{\mathrm{a}}$ & $80: 20^{\mathrm{a}}$ \\
\hline GM & 80.00 & 14.75 & $56.50^{\mathrm{c}}$ & $61.25^{\mathrm{b}}$ & $4.36^{\mathrm{b}}$ & $78: 22^{\mathrm{b}}$ \\
\hline Ga & 82.50 & 15.00 & $64.13^{\mathrm{a}}$ & $52.50^{\mathrm{c}}$ & $4.15^{\mathrm{c}}$ & $75: 25^{\mathrm{c}}$ \\
\hline Gm & 82.50 & 15.13 & $64.25^{\mathrm{a}}$ & $54.38^{\mathrm{C}}$ & $4.20^{\mathrm{C}}$ & $76: 24^{\mathrm{C}}$ \\
\hline Gf & 84.38 & 15.13 & $45.63^{\mathrm{d}}$ & $34.38^{\mathrm{d}}$ & $3.88^{\mathrm{d}}$ & $75: 25^{\mathrm{C}}$ \\
\hline Gi & 80.63 & 15.00 & $42.88^{\mathrm{e}}$ & $36.25^{\mathrm{d}}$ & $4.14^{\mathrm{c}}$ & $75: 25^{\mathrm{C}}$ \\
\hline SEM & 0.31 & 0.38 & 1.08 & 1.83 & 0.03 & 0.53 \\
\hline
\end{tabular}

${ }^{\mathrm{abc}}$ Means in the same column with different superscripts are statistically different at $5 \%$ level of significance. Germ. $=$ Germination; Harv. = Harvest; ZR = Zero fertilization; NPK = NPK (15-15-15) fertilizer; GM = Goat manure; Ga = Glomus agregatum; $\mathrm{Gm}=$ Glomus mossae; $\mathrm{Gf}=$ Glomus facultative; $\mathrm{Gi}=$ Glomus intraradices; $\mathrm{SEM}=\mathrm{Standard}$ error of the mean .

Table 3: Fodder nutrient concentrations of Moringa oleifera as influenced by fertilization regimes

\begin{tabular}{|c|c|c|c|c|c|c|}
\hline $\begin{array}{l}\text { Fertilization } \\
\text { regime }\end{array}$ & \multicolumn{2}{l}{ Leaf nutrient concentrations } \\
\hline & $D M(\%)$ & $N(g)$ & $A D F(\%)$ & $N D F(\%)$ & $P(g / 100 g)$ & Ca $(g / 100 g)$ \\
\hline ZR & 27.50 & 3.05 & 28.50 & 36.00 & 0.40 & 0.90 \\
\hline NPK & 28.00 & 3.20 & 28.00 & 35.80 & 0.42 & 1.00 \\
\hline GM & 27.45 & 3.10 & 25.80 & 36.75 & 0.50 & 1.05 \\
\hline Ga & 27.50 & 3.18 & 27.50 & 35.50 & 0.45 & 1.10 \\
\hline Gm & 28.20 & 3.10 & 28.20 & 36.45 & 0.55 & 1.00 \\
\hline Gf & 27.00 & 3.15 & 28.50 & 35.75 & 0.50 & 1.20 \\
\hline Gi & 27.50 & 3.16 & 26.00 & 36.50 & 0.45 & 1.15 \\
\hline
\end{tabular}

Germ. = Germination; Harv. = Harvest; ZR = Zero fertilization; NPK = NPK (15-15-15) fertilizer; GM = Goat manure; Ga = Glomus agregatum; $\mathrm{Gm}=$ Glomus mossae; $\mathrm{Gf}=$ Glomus facultative; $\mathrm{Gi}=$ Glomus intraradices;

CONCLUSIONS AND RECOMMENDATIONS:

Goat manure and two of the investigated AMF, Glomus agregatum and Glomus mossae appeared as feasible and practical alternatives to mineral (NPK) fertilization for the production of Moringa oleifera in terms of total biomass yield and the resulting fodder:stem ratios. The resulting forages, irrespective of the fertilization treatment, produced fodders of comparative nutritive values that meet the nitrogen requirements of ruminants, as well as contained $\mathrm{Ca}$ and $\mathrm{P}$ at levels higher than critical levels for small ruminants and cattle. In terms of relative availability and cost, however, goat manure appears to have an edge over the investigated AMF. An additional advantage with goat manure is nutrient cycling, a cardinal principle in organic agriculture.

\section{ACKNOWLEDGEMENTS}

- This study was made possible with the financial support of the IDRC-funded project, "Scaling-up Agricultural Innovations and Food Security Systems In The Gambia and 
Sierra Leone Integrated Peri-Urban Systems: Horticulture and Livestock in West African Cities (Phase 3)" based in International Trypanotolerance Centre, The Gambia.

- Dr. Mamadou Gueye, MIRCEN/Laboratoire Commun de Mocrobiogie IRD-ISRA-UCAD, Dakar, Senegal for the provision of the AM fungi

- The staff of the soil laboratory of National Agricultural Research Institute (NARI), Brikama, The Gambia

\section{REFERENCES}

Agriculture and Farming in The Gambia (2012). Gambia Agriculture. Available at www.accessgambia.com/information/farmingagriculture.html

Akhtar, M. S. and Siddiqui, Z. A. (2007). Bio-control of a chickpea-rot disease complex with Glomus intraradices, Pseudomonas putida and Paenibacillus polymyxa. Aust. Plant Pathol., 36: 175 - 180

Akinbamijo, O. O., Adediran, S. A., Nouala, S. and Saecker, J (2004). Moringa fodder in ruminant nutrition in The Gambia. Retrieved September 16, 2008, from www.moringanews.org/documents/Fodder.doc

Ambe, A. G. (2001). Les fruitiers sauvages cosmetibles des savanes guineennes de Cote d'Ivoire: etat des connaissances par une population locale. les Malinke. Biotechnol. Agron. Soc. Environ. 5(1): 43 - 58.

ANKOM Methods (2001a). Acid Detergent Fibre in Feeds; Filter Bag Technique. ANKOM Technology Corporation, Macedon, NY.

ANKOM Methods (2001b). Neutral Detergent Fibre in Feeds; Filter Bag Technique. ANKOM Technology Corporation, Macedon, NY.

AOAC (2000). Association of Official Analytical Chemists: Official Methods of Analysis. Washington DC, USA.

Aregheore, E. M. (2004). Nutritive value of sweet potato (Ipomea batatas (L.) Lam ) forage as goat feed: Voluntary intake, growth and digestibility of mixed rations of sweet potato and batiki grass (Ischaemum aristatum var. indicum). Small Ruminant Research, 51: $235-241$.

Awodun, M.A., Omonijo, L. I. and Ojeniyi , S.O. (2007). Effect of Goat Dung and NPK Fertilizer on Soil and Leaf Nutrient Content, Growth and Yield of Pepper. International Journal of Soil Science, 2: 142-147. http://scialert.net/abstract/?doi=ijss.2007.142.147

Becker, K. (1995). Studies on utilization of Moringa oleifera leaves as animal feed. Institute for Animal production in the Tropics and Subtropics, University of Hohenheim, Stuttgart, 480: 15

Bobb, M. T., Touray, O. and Dampha, A. (2005). Assessment of vulnerability to change in the rangelands and livestock sector and adaptation measures in The Gambia. Consultancy Report for NAPA Project LDL 23282724 4699, 21p.

Bose, B and Mishra, T. (1992). Response of wheat seed to pre-sowing seed treatments with $\mathrm{MgNo}_{3}$. Ann Agr Res 13, 132 - 136.

Bourn, D. M., Reid, R., Roger, D., Snow, B. and Wint, W. (2001). Environmental change and the autonomous control of tsetse and trypanosomosis in Sub-Saharan Africa. Oxford: ERGO Carling, D. E. and Brown, M. F. (1980). Relative effect of VA Mycorrhizal Fungi on the growth and yield of soybean. Soil Sci. Soc. Am. J. 44: 528532 .

Ceesay, M. A. (2004). Management of rice production systems to increase productivity in The Gambia, West Africa. A dissertation submitted to the Faculty of Graduate School of Cornell University in partial fulfillment of the requirements for the degree of Doctor of Philosophy, 159pp

Cole, A., Sanyang, K., Marong, A. J. and Jadama, F. (2005). Vulnerability and adaptation assessment of the agricultural sector of The Gambia to climate change. Consultancy Report for NAPA Project LDL 23282724 4699, 36p.

De Vogel, E. F. (1980). Seedlings of cotyledons. Centre for Agricultural Publishing and Documentation, Wageningen, The Netherlands.

Diack, A., Sanyang, F. B. and Munstermann, S. (2005). Lactation performance on-station of $\mathrm{F} 1$ crossbred cattle in The Gambia. Livestock Research for Rural Development. Volume 17, Article \#140. Retrieved October 17, 2009, from http://www.Irrd.org//rrd17/12/diac17140.htm

FAO (1997). The national agricultural research system of The Gambia: analysis and strategy for the long term. Final report. Field Document TCP/GAM/6611/FAO, 193pp

FAO (2002). The state of food insecurity in the world. A publication of the Food and Agriculture Organization (FAO) of the United Nations, Vialle delle Terme di Caracalla, 00100, Rome, Italy.

Farias, S. G. G., Freire, A. L. O., Santos, D. R., Silva, R. B. and Freire, J. L. O. (2008). Responses of Moringa oleifera Lam. plants inoculated with mycorrhizal fungi and submitted to water stress. Engenharia Ambiental: Pesquisal et Tecnologia, 5 (3): 36 - 46.

Foild, N., Makkar, H. P. S. and Becker, K. (2001). The potential of Moringa oleifera for agricultural and industrial uses. In: "The Miracle Tree- The Multiple 
Attributes of Moringa" (Ed. Lowell J Fuglie). Church World Service, Dakar, Senegal. 45 - 76.

Fukai, S. (1999). Phenology in rain-fed lowland rice. Field Crop Research, 64: 51 - 60.

Guissou, T. (2009). Contribution of arbuscular mycorrhizal fungi to growth and nutrient uptake by jujube and tamarind seedlings in a phosphate (P)-deficient soil. African Journal of Microbiology Research, 3(5): 297 . 304

Hartmann, H. T., Kester, D. E., Davies, F. T. and Geneve, R. L. (2002). Plant Propagation: Principles and Practices. $7^{\text {th }}$ Edition, Prentice Hall.

Hol, G. W. and Cook, R. (2005). An overview of arbuscular mycorrhizal fungi-nematode interactions. Basic Appl. Ecol., 489 - 503.

Jahn, S. A., Musnad, H. A. and Burgstaller, H. (1986). The tree that purifies water: cultivating multipurpose Moringaceae in the Sudan. Unasylva, 38: 23 - 28.

Luu Huu Manh, Nguyen Nhut Xuan Dung and Tran Phung Ngoi (2009). Introduction and evaluation of Moringa oleifera for biomass production and as feed for goats in the Mekong Delta. Livestock Research for Rural Development. Volume 17, Article \#104. Retrieved August 22, 2012, from http://www.Irrd.org//rrd17/9/manh17104.htm

McDowell, L. R. (1985). Nutrition of grazing ruminants in warm climates. Academic Press, Orlando, FI., USA, 443pp.

Morton, J. F. (1991). The Horseradish tree, Moringa pterygosperma (Moringaceae) - A boon to arid lands? Econ. Bot. 45: 318 - 333.

Nair, P. K. R. (1998). Directions in tropical agroforestry research: past, present and future. Agrofoerestry Systems, 38: 223 - 245.

NAPA (2007). Gambia National Adaptation Programme of Action on Climate Change. A document of Government of The Gambia in collaboration with GEF, GOTG and UNEP.

NEA (1997). The Gambia state of the environment. A report prepared by National Environment Agency (NEA), Banjul, The Gambia, 125pp

Nkomo, J. C. and Gomez, B. (2005). Estimating and comparing costs and benefits of adaptation projects: Case studies of South Africa and The Gambia. Final report submitted Assessments of Impacts and Adaptations to Climate Change (AIACC). Project No. AF 47, START, Washington, 137pp

Norton, B. W. (1998). The nutritive value of tree legumes. In: Forage tree legumes in tropical agriculture (Editors: R C Gutteridge and H M Shelton), pp 177-191. http://www.fao.org/ag/AGP/AGPC/doc/Publicat/Gutt- shel/x5556e0j.htm\#4.1\%20the\%20nutritive\%20value\% 20of\%20tree\%20legumes

Nouman, W., Siddiqui, M. T., Basra, S. M. A., Afzal, I. and Rehman, H. U. (2012). Enhancement of emergence potential and stand establishment of Moringa oleifera Lam. by seed priming. Turk J Agric, 36: 227 - 235.

Odeyinka, S. M., Hector, B. L. and Ørskov, E. R. (2003). Evaluation of the nutritive value of the browse species Gliricidia sepium (Jacq.) Walp., Leucaena leucocephala (Lam) de Wit. And Cajanus cajan (L) Millsp. from Nigeria. Journal of Animal and Feed Sciences 12: $341-349$.

Okoli, I. C., Anunobi, M. O., Obua, B. E. and Enemuo, V. (2003). Studies on selected browses of southeastern Nigeria with particular reference to their proximate and some endogenous anti-nutritional constituents. Livestock Research for Rural Development 15 (9). http://lrrd.cipav.org.co//rrd15/9/okol159.htm

Olayinka, A. (1990). Effect of lining and poultry manure additions on $\mathrm{C}, \mathrm{N}$ and $\mathrm{P}$ mineralization in an acid ultisol. Ife J. Agric., 12: 45-52.

Oliveira Jr. S. de; Souto, J. S., Santos, R. V. dos; Suoto, P. C.and Maior Junior S. G. S. (2009). Fertilization with different manures in the cultivation of Moringa (Moringa oleifera Lam.). Revista Verde de Agroecologia e Disenvolvimento Sustentavel, 4 (1): 125-134.

http://www.gvaa.com.br/revista/index.php/RVADS/art..

Olivier, C. (No date). Leaf Production: Intensive Moringa oleifera cultivation in the north of Senegal. Moringa oleifera - Scientific Reviews. http://www.moringatree.co.za/reviews2.html

Peters, J. B. and Schulte, E. E. (1996). Using plant analysis to guide research and extension programs in The Gambia. Commun. Soil Sci.Plant Anal., 27 (5 - 8): $1311-1329$

Price, M. L. (1985). The Moringa Tree. ECHO Technical Note. Educational Concerns for Hunger Organization, N. Ft. Meyers, FL. http://chenetwork.org/files pdf/Moringa.pdf

PSIP (2007). Department of State for Agriculture "Periurban Small Holder Improvement Project", The Gambia. Peri-urban Project: Making a Positive Impact on the Lives of Peri- urban Farmers. 14pp. Retrieved January 8, 2010, from http://www.agrigambia.gm/docs/periurban_brochure.pd $f$

Radovich, T. J. K. (2009). Arbuscular Mycorrhizal Dependency of Three Moringa Genotypes. Proceedings of the 2009 Annual Conference of The American Society for Horticultural Science. Laclede (Millennium Hotel St. Louis). ashs.confex.com/ashs/2009/.../Paper1425.html 
Reynolds, L., Attah-Krah, A. N. and Francis, P. A. (1992). Alley Farming with Livestock: Guidelines. Humid zone research site, ILCA, New York, 20pp

Santos, A. R. F. D., Renata, S. M., Roberio, A. F. and Alexandro, S. B. (2011). Water pre- hydration as priming for Moringa oleifera Lam. seeds under salt stress. Tropical and Subtropical Agroecosystems, 14 $201-207$.

SAS (1998). SAS User's Guide Statisyics. SAS Inc. Cary, North Carolina 1998 Edition.

Sharma, G. K. and Raina, V. (1982). Propagation techniques of Moringa oleifera Lam, In: Improvement of Forest Biomass, Indian Society of Tree Scientists, Solan, HP, India, 175 - 181.

Smith, G. S. (1987). Interactions of nematodes with mycorrhizal fungi, In: Veech, J. A. and Dickson, D. W. (Eds.), Vistas on Nematology, Society of Nematologists, Hyatsville, Maryland, USA, 292 - 300.

Smith, M.A.K. and Ayenigbara, E.A. (2001). Comparative growth and nutrient composition of Indian spinach in an enriched humid tropical environment. Afr. Crop Sci. Conf. Proc., 5: 1007-1013.

Smith, S. A. and Read, D. (2008). Mycorrhizal Symbiosis. 3rd edition, Elsevier Academic Press, London

Sudova, R., Jurkiewicz, A., Turnau, K. and Vosatka, M. (2007). Persistence of heavy metal tolerance of the arbuscular mycorrhizal fungi Glomus intraradeces under different cultivation regimes. Symbiosis 43: 71 81.

Tedonkeng, P. E., Boukila, B., Solefack, M. M. C. and Kana, J. R. (2004). Germination potential of Moringa oleifera Lam. under different treatments in Dschang in the highlands of Western Cameroon. J Camer Acad Sci 4: 199 - 203.

Wilson, D. O. (1988). Differential plant response to inoculation with two VA Mycorrhizal fungi isolated from a low pH soil. Plant Soil, 110: 69 - 75.

Yamato, M., Ikeda, S. and Iwase, K. (2009). Community of arbuscular mycorrhizal fungi in drought-resistant plants, Moringa spp., in semiarid regions in Madagascar and Uganda. Mycoscience, 50: 100 - 105. 